INTERNATIONAL JOURNAL OF RESEARCHES IN BIOSCIENCES, AGRICULTURE AND TECHNOLOGY (c) VISHWASHANTI MULTIPURPOSE SOCIETY (Global Peace Multipurpose Society) R. No. MH-659/13(N) www.vmsindia.org

\title{
CHECKLIST OF ICHTHYOLOGICAL FAUNA OF WASHIM DISTRICT, MAHARASHTRA, INDIA
}

Gulhane R. A.

P. G. De partment of Zoology, S. S. S. K. R. Innani Mahavidyalaya Karanaja (Lad), Dist. Washim (M.S.) India, 444105

\begin{abstract}
:
Washim district is a dis trict of Mahara shtra state in central India. It is trans ve rse by many rive rs with their nume rous tributaries. The study was conducted during June 2014 to August 2017. The se rive r hosts many of fish species; total of 36 species belonging to 11 families were recorded. These families were; Cyprinidae (20), Channidae (03), Mastocembelidae (03), Ambassidae (02), Bagridae (02), Siluridae (02), Gobiidae (01), Notopteridae (01), Saccobranchidae (01), Clariidae (01), and Belonidae (01). The rive $r$ and tanks of studied area have faced major alterations in the recent years due to several an thropogenic activities like increasing urbanization, industrialization and various recreational activities. Since the fish fauna in Washim District also supports the livelihood of se veral economic classes. So there is an urgent need to understand the conservation prioritie s and to design and implement conservation action plans.
\end{abstract}

Key words: Washim, Freshwater fish fauna, River ecosystem, Threats

\section{Introduction:}

The biological diversity of the earth and its origins has long been a source of amazement and curiosity (Joshi et al., 2013). The diversity of fish has long been a source of amazement and curiosity. Around the world approximately 22,000 species of fishes have been recorded out of which $11 \%$ are found in India that is about 2500 species of fishes of which, 930 live in freshwater and 1,570 are marine (Kar, 2003; Ubharane et al., 2011). From 18 century till to date various pioneers have been studied about Taxonomy and Ichthyofaunal diversity (Hamilton, 1822; Day, 1878; Menon, 1992) from diffe rent rivers. However scanty information is available on fishes hence an attempt has been made here to present piscine inventory from the Washim District (M.S.).

Washim district is district of

Maharashtra state in central India. The district occupies an area of $5150 \mathrm{sq.km}$. The district is bounded by Amravati, Yavatmal, Buldhana and Akola districts. The district comprises of several rivers and impounded water sources with their numerous tributaries (Washim Gaze tteer 2017). These rivers and Tanks have faced major alterations in the recent years due to increasing urbanization, industrialization and various recreational activities. Reassessment of the fish fauna and identifying the threats, so as to build baseline information for possible conservation action plans are thus a priority. For the current study, stretches of the rivers were sampled to identify the current status and threats to the freshwater fish fauna of Washim District (M.S.) India.

\section{Methodology:}

Fish we re collected from local fisherman and local marke ts located on the rive rs from June 2014 to August 2017. Fish were preserved in 4\% formaldehyde and identified using available lite rature (Day, 1996; Menon, 1987, 1992; Talwar and Jhingran, 1991; Jayaram, 2010; Eschmeyer and Fricke, 2011). Assuming that the fishing effort for a given type of net (gill net or drag net) was constant, the relative abundance of the fish was grossly categorized (for each type of net separately) into four categories, namely: abundant (76-100\% of the total catch), common (51-75\% of the total catch), moderate (26-50\% of the total catch) and rare (1-25\% of the total catch).

\section{Results and Discussion:}

During study, total of 36 species belonging to 11 families were recorded (Table 1). These families were; Cyprinidae (20), Channidae (03), Mastocembelidae (03), Ambassidae (02), Bagridae (02), Siluridae (02), Gobiidae (01), Notopteridae (01), Saccobranchidae (01), Clariidae (01), and Belonidae (01) we re recorded(Figure 1). Of these species; 08 were Abundant, 09 were Common, 14 were Moderate while 05 were Rare. From the observed species, Catla catla, Labeo rohita and Clarias batrachus are most commercially important fishes. Previously Lohar and Borse (2003) was reported 24 fish species belonging to 7 families in Tapi river. As well Joshi et al., (2012) were reported 20 species of 7 families from Purna river. In these reported fishes, Cyprinidae family was more dominant. Many researchers reported the strong dominance of Cyprinidae family in their inves tigations. 
Table 1: Ichthyological Fauna of Washim District of Maharashtra (India).

\begin{tabular}{|c|c|c|c|c|}
\hline Sr. & Family & Species & Auth or & Abundance \\
\hline 1. & Cyprinidae & Acanthocobities murreh & Sykes, 1839 & Abundant \\
\hline 2. & & Amblypharyngodon mola & Hamilton, 1822 & Moderate \\
\hline 3. & & Catla catla & Hamilton, 1822 & Abundant \\
\hline 4. & & Cirrh in a mrigala & Hamilton, 1822 & Abundant \\
\hline 5. & & Crossocheilus latius & Hamilton, 1822 & Moderate \\
\hline 6. & & Ctenopharyngodon idella & Steindachner, 1866 & Moderate \\
\hline 7. & & Cyprinus carpio & Linnaeus, 1758 & Rare \\
\hline 8. & & Garra Mullya & Sykes, 1839 & Common \\
\hline 9. & & Labeo baggut & Sykes, 1839 & Rare \\
\hline 10. & & Labeo bata & Hamilton, 1822 & Rare \\
\hline $\begin{array}{l}11 . \\
12 .\end{array}$ & & $\begin{array}{l}\text { Labeo calbasu } \\
\text { Labeo rohita }\end{array}$ & $\begin{array}{l}\text { Hamilton, } 1822 \\
\text { Hamilton, } 1822\end{array}$ & $\begin{array}{l}\text { Moderate } \\
\text { Common }\end{array}$ \\
\hline 13. & & Osteobrama cotio & Hamilton, 1822 & Moderate \\
\hline 14. & & Pethia ticto & Hamilton, 1822 & Common \\
\hline 15. & & Puntius saphore & Hamilton, 1822 & Common \\
\hline 16. & & Puntius sarana & Hamilton, 1822 & Rare \\
\hline 17. & & Puntius ticto & Hamilton, 1822 & Moderate \\
\hline 18. & & Rasbora daniconious & Hamilton, 1822 & Common \\
\hline 19. & & Salmophasia bacaila & Hamilton, 1822 & Common \\
\hline 20. & & Salmophasia balooki & Sykes, 1839 & Common \\
\hline 21. & Ambassidae & Chanda nama & Hamilton, 1822 & Moderate \\
\hline 22. & & Parambassis ranga & Hamilton, 1822 & Common \\
\hline 23. & Gobiidae & Glossogobius giuris & Hamilton, 1822 & Moderate \\
\hline $\begin{array}{l}24 . \\
25 .\end{array}$ & Bagridae & $\begin{array}{l}\text { Mystus cavasius } \\
\text { Sperata seenghala }\end{array}$ & $\begin{array}{l}\text { Hamilton, } 1822 \\
\text { Sykes, } 1839\end{array}$ & $\begin{array}{l}\text { Abundant } \\
\text { Moderate }\end{array}$ \\
\hline 26. & Notopteridae & Notopterus notopterus & Gunther, 1839 & Rare \\
\hline 27. & Siluridae & Ompok bimaculatus & Bloch, 1793 & Moderate \\
\hline 28. & & Wallago attu & Schlegel, 1839 & Moderate \\
\hline 29. & Saccobranchidae & Heteropneustes fossilis & Bloch, 1793 & Moderate \\
\hline 30. & Clariidae & Clarias batrachus & Linnaeus, 1758 & Abundant \\
\hline 31. & Channidae & Channa punctatus & Bloch, 1793 & Abundant \\
\hline 32. & & Channa striatus & Bloch, 1793 & Abundant \\
\hline 33. & & Channa orientalis & Bloch, 1793 & Common \\
\hline 34. & Mastocembelidae & Mastocembelus armatus & Lecepede, 1800 & Moderate \\
\hline 35. & & Mastocembelus pancalus & Hamilton, 1822 & Moderate \\
\hline 36. & Belonidae & Xenentodon cancila & Hamilton, 1822 & Abundant \\
\hline
\end{tabular}

During study, the ave rage number of specimens collected in different seasons. For comparing the catch success in different season, the average values of catch success we re used as a simple mean of total species collected per attempt. Catch success was highest in Monsoon months followed by winter while it was comparatively low in Summer. Previously, Sakhare (2001) was reported 23 species belonging to 07 order where Cyprinidae family is dominant with 11 species from Jawalgaon reservoir Solapur district Maharashtra. Battul et al. (2007) reported 18 species from Ekruckh lake Solapur district where Cyprinidae family is dominant with 8 species, Khedkar and Gynanath. (2005) reported 37 species from Is sapur dam district Yavatmal where Cyprinidae family is dominant with 20 species. Sharma (2008) reported 87 species under 36 genera under the Cyprinidae family from freshwater of Nepal. Shinde (2009) observed 11 species under 10 genera under the Cyprinidae family from Harsul Savangi dam district Aurangabad (M.S). Ubharane et al (2011) observed that the 27 species belongs to 11 families where Cyprinidae family was dominant with 13 species from Ambadi dam of Aurangabad (M.S.) India.

The fishing operation goes on by the local fisherman throughout the study period with low catches in monsoon compare to high harvest in post monsoon season. River ecosystem of Washim district hosts a number of fish species. But the ichthyological fauna of rivers is under threat as a result of several anthropogenic interferences. Other anthropogenic activities such as deforestation leading to siltation, recreational activities and sand mining are common in most of the stretches of the river. 
The fish fauna of rivers is also subjected to over fishing for consumption. Inorganic pollution of the river due to industrial and agricultural activities is another important threat to the fish fauna.

In conclusion, the rivers of Washim District hosts a number of freshwater fish species. However, the fish fauna in the study are a is threatened due to several anthropogenic activities like deforestation, over fishing, sand mining, recreational activities, brick kiln, and organic and inorganic pollution. Since the fish fauna in Washim District also supports the livelihood of seve ral economic classes. So there is an urgent need to understand the conservation priorities. Fishery department should adopt Legislative measure for conservation of commercially significant fishes which may disappear from rivers of Washim District (M.S.) India.

\section{References:}

Battul, P.N., R.A Rao, K.R. Navale, M.B. Bagale and N.V Shah. (2007). Fish Diversity from Ekrukh Lake Near Solapur Maharashtra. J. Aqua. Biol., 22 (2): 68-72.

Day, F. (1878). The fishes of India, being a natural history of the fis hes known to inhabit the seas and fresh waters of India, Burma and Ceylon. Vol. I and II. Ceylon text and atlas in 4 pts., London

Day, F. (1986). The Fishes of India; Being A Natural History of the Fishes Known to Inhabit the Se as and Fresh Waters of India, Burma, and Ceylon. Vol. 1 and 2. Today and Tommorow's Book Agency, 778pp.

Eschmeyer W.N. and R. Fricke (eds.) (2011). Catalog of Fishes electronic version. http:/ / research.calacademy.org/ ichthyology/catalog/fishcatmain.asp. Online version dated 29 March 2011. Downloaded on 22 April 2011.

Hamilton B. (1822). An account of the fishes found in the river Gangas and its branches. Vol. I-VII. Printed for Archibald constable and company, Edinburgh and Hurst, Robinson and Co - 90, Cheapside London. pp: 405.

Hammer $\varnothing$, Harper DAT and PD Ryan, (2001). Paleontological statistics software package for education and data analysis. Paleontologia Electronica. 4(1): 9 pp

Jayaram, K.C. (2010). The Freshwater Fishes of the Indian Region. Second Edition. Narendra Publishing House, Delhi, 616pp.
Joshi P. S., S. A. Tantarpale, V. T. Tantarpale and K.M. Kulkarni. (2012). Ichthyological fauna of Buldhana District, Maharashtra (India.). Onl. I. Inter. Res. J. 2 (2): 111-115

Joshi P. S., V. T. Tantarpale and K.M. Kulkarni. (2013). Fis hing Methods Commonly Employed In Buldhana District and Neighborhood, Maharashtra State (India) Bioscience Discovery, 4(1): 54-57.

Kar D. (2003). Fishes of Baraka drainage Mizoram and Tripura in A. Kumar, C. Bhaora and L.K. Singh, (eds.). APH Publishing cooperation, New Delhi. : 202-211.

Khedkar G.D. and G. Gynanath. (2005). Biodiversity and distribution of the fishes from the back waters of Iss apur re servoir dist Yeotmal, Maharashtra state India. Trends in Life Science (India) 2005, 20 (2): 117-126.

Lohar, P. S. and S. K. Borse (2003). Diversity of fish fauna in River Tapi, Maharashtra J. Aqua. Biol. 18(1): 47-49

Menon A.G.K. (1999). Check List of Freshwater fishes of India (ZSI) Culcutta Occasional paper no.175.ZSI Culcutta pp-306.

Menon, A.G.K. (1987). The Fauna of India and Adjacent Countries, Pisces, Vol-4, TeleosteiCobitoidea, Part-1, Homalopteridae. Zoological Survey of India, Kolkata, 259pp.

Menon, A.G.K. (1992). The Fauna of India and Adjacent Countries, Pisces, Vol-4, TeleosteiCobitoidea, Part-2 Cobitidae. Zoological Survey of India, Kolkata, 113 pp.

Sakhare .V.B. (2001). Ich thyofauna of Jawalgaon reservoir in Solapur district of Maharashtra. J. Aqua Biol., 16 (1 and 2): 31-33.

Sharma C. M. (2008). Freshwater Fishes, Fisheries and Habitat prospects of Nepal, Aquatic ecosystem, health and management vol. 11 (3):75-82 .

Shinde S.E., Paithane, R.Y Bhandare and D.L Sonawane. (2009). Ichthyofaunal diversity of Harsool Savangi Dam district Aurangabad (M.S) India. World J. Fresh Mar.Sci.1(3):141-143.

Talwar, P.K. and A.G. Jhingran (1991). Inland Fishes of India and Adjacent Countries. OxfordIBH Publishing Co. Pvt. Ltd., New Delhi, 1158pp.

Ubarhande S.B , J.T. Jagtap and S.R. Sonawane (2011). Ich thyofanal Dive rsity from Ambadi Dam, Taluka Kannad, District -Aurangabad (M.S.) Recent Research in Science and Technology 3(6): 34-37

Wilson E.O. (1992) . The Diversity of life. Be lknap press, Harvard Univ., Cambridge. MA. 